\title{
Multiple Revolutions. Remediating and Re-enacting the Romanian Events of 1989
}

\author{
Mónika Dánél \\ Eötvös Loránd University (Budapest, Hungary) \\ E-mail: danel.monika@btk.elte.hu
}

\begin{abstract}
This study proposes a twofold analysis: the presumable strategies of the December 1989 events in Romania and their complexity as it appears in later filmic re-enactments. These re-enactments as theatrical "translations" offer a rhetorical reading of past events, and can also be seen as practices of memories inscribed in the body. The events are interpreted in the duality of the archival image and the acoustic/gestural memory, where the latter is understood as an atmospheric (bodily) memory. The disorientation or disinformation caused by the technical conditions, the circulation or lack of images, the alternating silences and chanting on the street make the past events incomprehensible and medially dissonant. ${ }^{1}$
\end{abstract}

Keywords: re-enactments of historical events, films about December 1989 in Romania, the experience of space, body and memory.

\section{Simulation, Collective Imaginary, Inner Strategies}

In relation to the Romanian events, there is a consensus regarding three particularities: this was the bloodiest regime change in the Eastern European bloc; the television was a medium that influenced the events - and thus its historicity appears as a media event -, and the events were dispersive. The documents, interviews, hypotheses ever growing in number, the different narrative versions nuance and modify today's memories. Their contradictory, dissonant nature indirectly also stages the reflexive understanding of the past event. Borrowing Michael Rothberg's idea, the 1989 Romanian events become comprehensible today as an event that takes shape at the crossing point of the

1 This work was supported by the project entitled Space-ing Otherness. Cultural Images of Space, Contact Zones in Contemporary Hungarian and Romanian Film and Literature (OTKA NN 112700) and by the János Bolyai Research Scholarship of the Hungarian Academy of Sciences. 
narratives of multidirectional memory (Rothberg, 2009). ${ }^{2}$ The simultaneous events of the period between the $21^{\text {st }}$ and $25^{\text {th }}$ of December 1989, the last public speech of Nicolae Ceauşescu and the execution of the Ceauşescu couple, make a chronological approach impossible. ${ }^{3}$ These couple of days stratify the various shaping, simultaneous narratives of a military coup d'état and a popular movement, revolt turning into a revolution, each with a different starting point. There are ideas that trace back the events to international - Russian, American or even Hungarian - conspiracies. ${ }^{4}$ Yet others emphasize the disruption within the system. The complex, discursive medium, through which one can relate to the events of that time, is created by the hybrid street protests partly organized and directed, and partly spontaneous. ${ }^{5}$ The "spontaneity" of the street events is also shaped by ideas of provocateurs. In the narrative of international interference, such is for example the suspicion that foreign agents existed in Timişoara, or the hypotheses about voice manipulations of agents of the yet existing Communist regime on the Palace Square meeting. Ceauşescu convened a mass meeting to the Palace Square on the $21^{\text {st }}$ of December 1989, and the speech he delivered (meant to condemn the events of Timişoara and demonstrate his power) was broadcast live on television. The interpretation of the Palace Square events is an excellent indicator of the divergent nature of the 1989 events in Romania. The archival evidence on the Revolution, the so-called Revolution Files, opened to public access in the summer of 2016, also revealed that it was about the collision of various strategies. One of the probable narratives claimed that a sound-and-light grenade

2 In addition to competitive narratives, which do not cancel each other's truth, we must also posit here the presence of simulated, manipulated narratives, which shaped the events with their non-truth as well.

3 I use the dates of the two events broadcast on television (in the case of the execution, the delayed images) because of their wide media circulation. The designation "beginning" and the "end" of the revolution is much more problematic. For instance, one of the currents of Romanian historiography (namely, the chronology of Alex Mihai Stoenescu) tries to overwrite the initiating (and partly Hungarian) character of the events at Timişoara on the $16^{\text {th }}$ of December 1989 , and replace it with the protest attempt at Iaşi on the $14^{\text {th }}$ of December.

4 E.g. this is the preconception of Susanne Brandstätter's film, Checkmate, which presents the Romanian events at the intersection of international strategies (see Brandstätter-Adameşteanu 2004). The film follows the visual dramaturgy of a chess game, compiling the memories and interpretations of an Eastern European representative of the American secret services, French and Romanian historians, Miklós Németh, the parents of a victim from Timişoara, and other characters. Miklós Németh mentioned, for instance, that Victor Stănculescu, one of the key figures of the events, who organized the technical conditions of the execution of the Ceaussescus, had a fair command of Hungarian, thus the linguistic conditions of a Hungarian conspiracy are met, and the film offers a possibility of Hungarian influence.

5 The military also has a twofold role in the narrative of the events. For a comprehensive summary of the hybrid narratives of the army and the Romanian revolution, see the groundbreaking study of Ruxandra Cesereanu (2009). 
was used in the square (Hodor, 2016). ${ }^{6}$ (This type of grenade was developed for creating confusion and disarming in hostage-taking situations, efficient mainly in closed spaces, emitting strong light and sound and making it impossible to sense the surroundings.) The agents of the Securitate and the Special Antiterrorist Unit, mingling with the crowd, used these devices to threaten the groups of protesters trying to invade the square. The panic and movement of the crowds created by the sound grenade was sensed by Ceauşescu himself, who archived the effect for posterity himself, as he had to stop his speech because of the noise, and the camera that filmed him recorded it. (The sudden sound that was created must have been quite drastic in the silence required for a public speech.) Also, his gaze pointed directly at the place where the order was broken. Simultaneously with this, as Hodor claimed, the men of the Securitate standing near Ceauşescu concluded that the "Comrade" was in danger, and their nervous movements also indicated it on the TV monitors. As a third component, Ilie Ceauşescu, the president's brother and deputy Minister of Defence, a fanatical producer of the idea of foreign (Hungarian and Russian) invasion, also carried out an intimidating action. In reference to the files of prosecutor Bogdan Licu, Mădălin Hodor claimed that Ilie Ceauşescu gave orders to use a special sound amplifying technique on the square. The president's brother thought that the grenade was an attack, so he had the pre-prepared track of "psychological war" connected to the amplifiers on the square, and this rumbling noise simulating tanks and airplanes triggered panic in the crowd. Hodor's article argues also that the dictator (code name "Comrade Oak") probably saw that there was no imminent danger, so he did not withdraw but tried to continue his speech (eventually completing it), and thus prevented a massacre (for there were armed soldiers all over on the surrounding buildings). This argumentation considers that Ceauşescu's interjections ("Ho, bă!", "Nu, mă, ho!” - in English, approximately: "Hey!”, “Hey, no!”) were instructions to stop the shooting. However, this interpretation is somewhat doubtful in the context of the images showing the insecurity on the dictator's face, and in the given situation it could have just as well referred to the fact that the dictator did not want to leave the balcony where he was standing.

The last public speech that was broadcast live has a historical value of a turning point: the disruption of the speech and the live transmission and the temporal distance between the two irrevocably revealed the insecurity, if not outright fear,

$6 \quad$ For the "psychological war" aired on the news of TV2 on December 21, 2016 at 19:29, see: http://stiri.tvr.ro/razboi-psihologic-in-21-decembrie-1989--armata-a-folosit-tehnica-specialapentru-a-induce-panica-la-mitingul-convocat-de-ceausescu_812738.html. Last accessed 22. 08. 2017. 
perceptible in the dictator's voice, visible on his face and movements, and on his entourage. At any rate, the camera archived the dictator's falling out of his role built up and practiced in the course of decades. Using the terms of Henri Lefebvre (Lefebvre 1991), in the moments of the disruption of his speech, Ceauşescu himself became the perceiver of the space that formed in the tension of the representation of space and spatial practice. The structure of the space that had previously been set as a panopticon (in a structure that objectifies people) lost ground because of the revolted occupants of the space, although their experience of the space was not readily visible. The effect, that is, the tension between the abstract (here: dictatorial) use of the space and the experience of the people who moved away from this abstract space, was "broadcast" by the dictator himself. Through him, or rather through the camera and the broadcast, the viewers could also perceive the live space for a short while. Paradoxically, he was the first who could experience the space and pass on the disruption in it thanks to the space representation constructed by the camera.

After this disruption, the previously centralized structure and representation disintegrated into the transmitted images and time planes of partly simultaneous and contradictory events. It was a media event in the sense that the TV studio turned from a space of representation into a location, amplifying the circulation of (phantom) images and further enhancing the dramatic sequence of events. The television had a decisive role in creating the image of the terrorists as the collective (imaginary) enemy. ${ }^{7}$ Supposedly, however, other technical simulations also assisted this image of the terrorists created in an unparalleled manner under the technical and mental conditions of the age to look real. ${ }^{8}$

So, while the simulations of the technical apparatus (and their circulation) coded and created the (manipulated) events of the age, other circumstances not unrelated to the technical conditions also shaped these in an invisible, implicit way. Based

The identity of the so-called "terrorist" has never been reassuringly solved. Ruxandra Cesereanu in her abovementioned book lists ten different versions. Presumably, it was Ceauşescu himself who first used the term "terrorist actions" in the context of an international conspiracy at the last meeting of the Central Committee. Then it appeared again in the language of the actors of the new power as the "terrorist phenomenon" (Nicolae Militaru), and as "certain terrorist gangs" (Ion Iliescu, interview for the BBC on the $23^{\text {rd }}$ of December 1989). Iliescu staged these "gangs" as the protectors of the escaped dictator and his wife. It gained different contexts in different narratives as an empty signifier, but it is a fact that cannot be avoided that after the $22^{\text {nd }}$ of December 1989 , the day the couple escaped, 942 people died, most of them having been shot in the head.

8 The authors of an article published in January 1990 thought it was possible that there were shooting points that simulated shots. Cf. Uluitoarea Tehnică a Teroriştilor. (The Amazing Techniques of the Terrorists) Adevărul (20. 01. 1990) https://romanianrevolutionofdecember1989.com/ uluitoarea-tehnica-a-teroristilor-adevarul-20-ianuarie-1990-p-2/. Last accessed 22. 08. 2017. 
on the memories of the participants, I think that the unspoken (hypothetical) strategies of the key individuals in the shaping of the events "collided" and led to various decisions. These inner strategies/narratives were created by the panoptic control as unspoken suggestions and suspicions. However, precisely by being unspoken, they led to decisions, because of the common knowledge of the structure of dictatorship. The virtual stage of the assumed power of phantom images created from simulations and the unspoken strategies was simultaneously efficient and operative. The duality between what the members of the hierarchical social structure knew, based also on each other's mutual supervision, and what they did not know because of the novelty of the situation created an open, malleable medium of suggestions and suspicions, where the responsibility of the individual decisions became stronger (this was the case, for example, of the army barrack commander from Târgovişte, Andrei Kemenici, who guarded the Ceauşescus in their last days). The strategies surrounding the execution of the couple were partly staged as such a virtual game. ${ }^{9}$ While the dictatorial structure was loosened by street movements, a play field for individual tricks or agendas also emerged. Supposedly, the group that had the strongest strategic vision was best in transferring the mental conditions based on mutual supervision, and turned the change into a long transition to a new status quo. (In the work of Harun Farocki and Andrei Ujică analysed later on and the restaging of Irina Botea, the process of the naming of this new political status quo signals the fluidity of the reproduction: Ion Iliescu would have been willing to leave the term "Socialist" in the name of the new party, but when he was told it was not the best idea, he easily agreed to name the party National Salvation Front, connected to the people of Timişoara. It was much less important how they called themselves as long as they represented the only centralized power. They had no language, no concept for the change.) For the other strategists, as soon as they

9 The participants of the nearly four-hour-long 1999 talk show, The Last Days of the CeauşescuCouple tried to legitimize the events of the execution and their own role in these through their own memories. The "show" also played on the reconstruction of the events by the choice of the location (the building of the Central Committee of the Romanian Communist Party, the former room of the Political Execution Committee), and later it exposed interpretations of the hypotheses and decisions of the actors, who shaped the events (Victor Stănculescu, Gelu Voican Voiculescu, Ion Cristoiu, Andrei Kemenici, Ion Boeru, Viorel Domenico, Constantin Lucescu, Constantin Paisie). The show can be watched online at: 3.06.1999 - Ultimele zile ale soților Ceauşescu (partea I): https://www.youtube.com/watch?v=sNw-gJuHzkg\&t=5579s, and 3.06.1999 - Ultimele zile ale soților Ceauşescu (partea a II-a): https://www.youtube.com/ watch?v=Tt1qXeZm1H4. Last accessed 22. 08. 2017. Corneliu Porumboiu's talk show imitation and parody 12:08 East of Bucharest (2006) can be interpreted in this media context of the 2000s. Radu Gabrea's feature film Three Days Till Christmas (2011) can be seen as a re-enactment of this archived show, as a staging of the self-reflective character of the remembering process, in which the participants think about their former decisions. 
sensed this centralized power, and because Communism had already conditioned them for it, their interest was to go with this change. This common interest brought into play the silent cooperation among the new people in power, due to which the so-called phenomenon of "terrorists" can still be only analysed in its effects and strategic functions. The apparatus that produced this phantom, which required human sacrifice still cannot be grasped in concrete terms and thus it still cannot be legally prosecuted. We can only trace the history of a word coming "from thin air," which gets stigmatized and demonized because of a television broadcast, which is attached to human sacrifice hovering above the dead bodies and which finally vanishes as a mere ghost. ${ }^{10}$ The phantom image is impossible to reconstruct, it fades compared to its extraordinary applicability. The transformation of the media and mental conditions of the age perceivable here must have had a role in the success of this phantom image: the society of those times lost precisely its most intimate lie-detecting sense because of the simulations and techniques of a fake reality, which repainted everything (even the leaves on the trees during one of the dictator's visits), under the influence of a blind faith in the regime change.

Stere Gulea's documentary University Square (Piața Universității, 1991) recorded the media traces of the long transition by archiving the 1990 events in Bucharest. The documentary follows the series of protests beginning with the $21^{\text {st }}$ of December 1989, which was eventually dispersed by the miners in June, and for which the then President Ion Iliescu was again placed under accusation in December 2016. On the one hand, we may observe the performative, community forming force of the sounds (singing, chanting) in this film. On the other hand, the archival images present all the techniques, with which the (new) power system - besides the physical violence of the miners - tries to purge the protesters from the square "linguistically" by stigmatizing their mere existence or names through a vulgarized political speech. ${ }^{11}$ Gulea's film also displays a certain continuity of gestures: at one point in the film (minute 58), for example, Ion Iliescu's hand repeats Ceauşescu's typical gestures. One can even say that Iliescu's body and language "narrates" the mental conditions of the age. The protesters also used the technique developed

10 The divergent semantic field of this word is shown also in the memorial show referred to in the previous note: Constantin Lucescu called in that show the sentence, to which he himself assisted as a defence lawyer, a simulacrum, while also saying that before they arrived at the courtroom they thought they were supposed to sentence two terrorists (doi terorişti).

11 Ion Iliescu, as the representative of the new power, called the protesters golani (rogues) in the Parliament, following Ceauşescu, who had called the protesters from Timişoara huligani (hooligans). After the events, in the RAI 2 interview he said that the miners helped to clean the traces of vandalism from the square, restoring the green area. And they also "hoed" people out of there, adds ironically the poet and journalist Mircea Dinescu in Gulea's film. 
to hail Ceauşescu in their chanting, but they tried to achieve something different through it. The new medium of the freedom of expression is the song, the solid refrain, which creates a commonly experienced sounding space. ${ }^{12}$

The multiple layers of technical and mental conditions, the media traces of trained, manipulated, simulated situations create the hybrid relational space, where one may get an image of the events as transmitted by the archives. The sounding materials (telephone conversations, oral orders) connected to representatives of the old-new power were those mostly left in the background in television broadcasts and archiving processes. At the same time, for the masses in the public spaces the event was created through the chanting, precisely in the medium and time of the sound, the sounding body, as the rhythm or a word or phrase "fixed" the faith in an imagined and desired change. The poet Mircea Dinescu's first free television statement, his hesitating speech turned into a performative message as he almost surprisingly found the expression We won! (Am învins!), and his body turned into a sounding medium while chanting it.

In my study, further on, I shall analyse the various re-enactments as corporeal modes of memory, first as practices that make the meaning of bodily performativity readable, understandable during the events of the age. Then, as a mode of remembrance, through which a strange past experience can become the experience of one's own body taking on the situation or figure of others. In the re-enactment, the hybridity of the archival traces inscribed into the body, both fictive or with a documentary value, highlights the discursive field of the media ingredients and strategies, while all this appears through the bodies' own experience. The archival image or scene of the past event transferred to the body disintegrates the body as a discursive space, a living archive.

\section{Re-Enactment as an Artistic Strategy and Practice}

The re-enactment as a performative act fundamentally reorganizes and stages the relationship of a historical event, of past and authenticity. As a hybrid genre of private and collective memory, it is an outstanding phenomenon of contemporary art, which creates specific formations relating to the historical

12 The Hymn of the Rogues (Imnul golanilor), composed by Cristian Pațurcă, was remembered as the hymn of the revolution. The refrain goes: "A loafer rather than a traitor, / A hooligan rather than a dictator, / A rogue rather than an activist, / Dead rather than a communist." (In the original: "Mai bine haimana, decât trădător, / Mai bine huligan, decât dictator, / Mai bine golan, decât activist, / Mai bine mort, decât comunist.") 
past in-between past (archives, memories) and present relations and concepts. A difference must be made between popular forms of historical re-enactments and artistic re-enactments. Inke Arns differentiates between the re-enactment used in criminology, experimental archaeology and live action role-play practiced in popular culture, when different groups re-enact historical events or past lifestyles as a hobby (Arns 2011). The author discusses the term re-enactment in relation to two others: living history, which is not necessarily connected to concrete historical events, it is the re-creation of a certain way of life; and live action role-playing, where the character is physically enacted, but apart from the previous two versions, it is based on fiction. However, "what all three forms - reenactment, living history, and live action role-playing - have in common, is that they allow access to history, or histories, through immersion, personification, and empathy in a way that history books cannot" (Arns 2011, 2).

Artistic re-enactments differ from these in their reference to the present: "the difference to pop-cultural re-enactments such as the re-creation of historic battles, for example, is that artistic re-enactments are not performative re-staging of historic situations and events that occurred a long time ago; events (often traumatic ones) are re-enacted that are viewed as very important for the present. Here the reference to the past is not history for history's sake; it is about the relevance of what happened in the past for the here and now. Thus one can say that artistic re-enactments are not an affirmative confirmation of the past; rather, they are questionings of the present through reaching back to historical events that have etched themselves indelibly into the collective memory" (Arns 2011, 2).

The re-enactment is present also because of the embodiment, "as a body-based discourse in which the past is reanimated through physical and psychological experience" (Agnew 2004, 330), making it possible to experience the historical past from within. In the role played as a corporeal experience, the play is not merely a role, but it turns into participation. The re-enactment changes the past event into individual experience, leaving traces on the body, and thus the traumas of the past change the players into (post-factum) witnesses (see Agnew 2004, 331). The re-enactments are agents where the past event can be experienced as personal, and as such cultural phenomena, they offer a reflection of historical discourses and make the great narratives of historiography democratic (see Agnew 2004, 335). The re-enactment as a practice that can be applied in education places the written history and the ritual and synchretic oral tradition in the relationship of history and memory side by side: it turns the memory into an intermedial, intercorporeal experience, and as such, it needs 
an interdisciplinary interpretation. In the spirit of Augusto Boal's concepts, it changes the Spectator into a Spect-Actor (Boal 2006), and this is something the interpreter cannot withdraw from either. The re-enactment as a contemporary artistic strategy, while it redefines the elements of art (e.g. the author's intention) and its audience, is committed to the historical consciousness as something that can be shaped, and is interested in understanding the historical events from the society of the present: that is, it reconnects the historical past (and indirectly art itself as a re-enactment) to contemporary society. It offers a divergent and nonlinear experience of history in-between the past and the present, the multiple viewpoints of a collective and private event, in the duality of an archived past and a bodily presence.

The growing number of re-enactments of the Romanian revolution betray a need for the processing of the past, as well as the collective significance and shocking, traumatic nature of archival images both for directly involved (Romanian, Hungarian, Romanian emigrant) artists, or foreign artists touched by news and broadcasts. It can be said that the works created not long after the events recreated the divergent media complexity of the events, while the later ones tended to understand other subjective viewpoints and narratives. However, in both cases they create the possible narratives of past events, at times even through the dual, distancing and implicating nature of humour. ${ }^{13}$

In what follows, I shall analyse the re-enactment strategies of the visual works of various genres. The plays of Caryl Churchyll Mad Forest (1990/1991), Harun Farocki and Andrei Ujică's Videograms of a Revolution (Videogramme einer Revolution, 1992), Susanne Brandstätter's Checkmate: Strategy of a Revolution (Schachmatt: Strategie einer Revolution, 2004), Corneliu Porumboiu's 12:08 East of Bucharest (A fost sau n-a fost?, 2006), Irina Botea's Auditions for a Revolution (2006), Milo Rau's The Last Days of the Ceauşescus (Die letzten Tage der Ceauşescus, 2009/2010), Radu Gabrea's Three Days Till Christmas (Trei zile până la Crăciun, 2011) and Petra Szőcs's The Execution (A kivégzés, 2014) are considered here as works, through which the re-enactment as a performative act stages the overlapping of the historical event and its media broadcast, displaying the Romanian revolution as a media event. At the same time, making the embodied scenes of the past alive raises awareness through enactment that the

13 The Romanian filmic tradition contains examples of both re-enactment - e.g. Lucian Pintilie's Reconstruction (Reconstituirea, 1968) - and technical transmission - e.g. Mircea Daneliuc, Microphone Test (Probă de microfon, 1980). These films expressed the transforming practice of re-enactment and transmission placed in the service of propaganda in (tragi)comedies with a necessarily critical voice in the ideological context of their times. 
dead, among whom the executed Ceauşescu-couple can be authentically enacted, but cannot be brought to life, and from the viewpoint of the family of the dead, the Romanian revolution cannot be abstracted as merely a media event of the transmitted images. However, there may be a consensus about that fact that the television broadcast had a central role during the Romanian revolution, television gained its media historical self-definition through this event.

My personal starting points are the images made in the family spaces of the Farocki-Ujică film: children and an elderly woman watch a television broadcast, while probably a family member is filming them (one of the children even looks into the camera) [Figs. 1-2]. The images transmit the faces and bodies at the intersection of a television broadcast and a recording camera in a private space, and indirectly also the presence of a handheld camera. The "intention" of a camera that strives to archive the gaze signals that this collective act of watching TV is an event. Showing the people watching without a sound (nobody asks them how they feel, what they think) places the image self-reflectively into the centre of the future viewer's attention, together with the disturbing tension of searching for meaning. Some of the re-enactments - such as those of Irina Botea and Petra Szőcs - can be seen as interpretations of these soundless, archived gazes.

"Silence is part of the signature of a totalitarian state." (Koselleck 1979, 289.) According to the evidence of the above images, the mediatized view of the fall and the dead bodies of those who were in control of silencing in a totalitarian regime (the Ceauşescus) also causes silence. The following archival images can be viewed as the staging of an untouchable media spectacle and viewing as a bodily experience [Figs. 3-4]. The hardly recognizable sight of the television image of the executed dictators causes an adult's hand to make a gesture of pointing, just like a child - who is not yet aware of the presence of the medium in-between the image and their own body - and wants to better understand or reach to what is there on the screen. The owner of the pointing hand - by the deictic nature of the pointing - tries to gain some sort of identification or knowledge in the spots of the screen.

I look at these archival images as signalling the media conditions of the age and recording the physical and mental experience of their contemporary viewing, the sight and effect of all the previously unimaginable television images (the silent watching and bodily reactions). The visual works analysed here are reenactments (performance, feature film, theatre performance, short film) of past events from various present perspectives, which stage the human presence of the participants of the events and fragments of the technical, media elements of the age, while also bearing the marks of the archival nature of the recorded 
images. A common feature of the films is the doubling, reflective retrospection of the re-enactment, while their different genres bring the divergent ways to light to understand the events of the age. Connecting the images above, the following question arises: how can the portrait of the dictator, retouched for twenty-five years to always look healthy, hanging on the walls of classrooms and public institutions, be "replaced" (if at all) in the eyes of children and adults with the image of the dead body lying on the ground in front of the wall? The sight of the screen as mediation without the possibility of touching also signals to me this gap between the media and the mental.

The events of 1989 in Romania earned the name of the first "televized revolution" because of the strategic role of the television, as it was for the first time in history when a revolution took place in live transmission, on TV as well, and the street became an extension of the studio, as Jean Baudrillard claims: "the moment that the studio became the focal point of the revolution [...] everybody ran to the studio to appear on the screen at any price or into the street to be caught by cameras sometimes filming each other. The whole street became the extension of the studio, that is, an extension of the non-place of the event or of the virtual place of the event. The street itself became a virtual space" $(1993,64)$. This resulted in a paradoxical situation: when every information comes from the $\mathrm{TV}$, the viewers should be simultaneously in front of the screen and in the place of action. At the same time, "when the TV becomes the strategic space of the event, it becomes unconditional self-reference” (Baudrillard 1993, 63). However, television as medium "teaches us indifference, distance, radical scepticism, unconditional apathy" (Baudrillard 1993, 70). All these contradictions create the common historical significance of television and events, as it conveys by these events, shaped in their turn also by the spectacle of the television, a new practice for all the previous uses of the television. Giorgio Agamben also considers that the role of the television is paramount: "in this way, truth and falsity became indistinguishable from each other and the spectacle legitimized itself solely through the spectacle. Timissoara is, in this sense, the Auschwitz of the age of the spectacle: and in the same way in which it has been said that after Auschwitz it is impossible to write and think as before, after Timissoara it will be no longer possible to watch television in the same way" $(2000,83)$. Vilém Flusser calls the relationship of reality and image in the Romanian event a "technical voodoo," and summarizes in his Budapest lecture held closest in time to the revolution that "there is no reality behind the image. There are realities in the image" (Flusser 1990). He emphasized the theatrical character of the events that he considered a 
turning point, in the Lessingian sense of theatre: "to provoke sympathy and fright" (Flusser 1990). If we accept this claim, then the re-enacted versions - theatralized, dramatized, translated into foreign languages and relocated to different spaces share the repeatable theatricality of the past event. ${ }^{14}$ Nevertheless, they do not distance themselves by this, but elicit a series of questions. What are the mediaand performative relations that the re-enactments stage in the remix-practices of a general prosumer (a productive user/consumer) in the age of post-media, and how do these differ from the media uses of the contemporary event? Where does the event happen in this case? The participants to the event were indeed the participants of that particular event that we later experience as such? If "the real experience is in the image, what happened behind the image is no use to us" (Flusser 1990), then what kind of role can we find for ourselves as viewers inbetween archival and re-enacted images? If we merely look at it as a media event, then how can we deal with the victims?

\section{Language Use, Technical Background and Intonation}

The earliest artistic rendering of the Romanian revolution, to the best of my knowledge, is Caryl Churchill's drama entitled Mad Forest. ${ }^{15}$ Grasping the events as language, drama and theatre performance is also important because it is the first treatment of the revolution broadcast in and fought through images. The play, making use of the cross-section of viewpoints in-between insider (Romania) and outsider (England), stages the parallelism and the intersections of a variety of private and public voices, and this way it achieves the same polyphony within the field of language that appears in the camera movement of the later FarockiUjică videogram. The play acknowledges the cultural in-betweenness through bilingualism (every scene begins with a common Romanian sentence repeated in English, as if an English tourist practiced Romanian sentences), translation (through the figure of a Translator character), musical, sounding elements (the Romanian national anthem after 1990 and the chanted slogans during the

14 In Irina Botea's understanding, re-enactment as a construction is about "sharing” and it raises several questions for the present, so it can be regarded as truly real (Picard 2011).

15 In 1990 Caryl Churchill travelled to Bucharest with senior students of the London-based Central School of Speech and Drama and together with students of the Ion Luca Caragiale University of Theatre and Film they created the drama staged in September that year at the National Theatre of Bucharest, and in October at the Royal Court Theatre of London. The play is still a favourite piece of young actors worldwide, offering a possibility of displaying cultural differences through a historical event. My interpretation uses the text of the play and parts of performances found on the internet. 
revolution), and the ironic inclusion of western stereotypes (the figure of the Vampire), while it deals with the (cultural) transmittability, the condition for understanding outstanding events. ${ }^{16}$ The cultural in-betweenness also shows that the events can only be understood through the distance of retrospection, through the dual authenticity of those who directly experienced the events and those who perceived them through various media and bodily renderings. It stages the "objectivity of multiple viewpoints," as a Romanian critic states, of which the Romanians who were closely affected by the events, were not capable (see Pascariu 2007). The play narrates the events through the intimate and personal everyday practices of two families, and it also signals the gaps of the events. In the juxtaposition of private voices and the emphatic silences between them, ${ }^{17}$ it highlights their lack of adjustment. By way of silence and distancing bilingualism, an alienation technique comes into play through which "the refraction of the speech and the activation of silence brings about the spatialization of the truth" (Pascariu 2007). In the three-act drama the revolution takes place in the second act called December, between two weddings, stepping out of the restricted family circle suggested by a series of formal introductory sentences. The characters say their unconnected sentences like a short introduction in a foreign language. The events are transmitted through these isolated parallel voices. The first act begins with a collective family recitation of a poem eulogizing Elena Ceauşescu, while in the last act they playfully reenact collectively in a flat, like children, the condemnation and execution of the dictator and his wife. It is as if they could not escape the phantom-like presence of the one-time dictators and the trauma of the execution even in their private daily lives. The play displays the lack of balance between the collective and the private sphere, together with all the questions impossible to answer - such as whether there was a revolution or not (an anticipation of Porumboiu's film), or the gestures and language used by Iliescu (seen in Gulea's film) - as a search for, or inefficiency of, language. Through the Hungarian protagonist (Ianoş) and the various ways of relating to him, the play also highlights nationality problems, and it ends with a danse macabre-like

16 Such sentences referring to the conditions of the age start the scenes: "Lucia are patru ouă. Lucia has four eggs." "Cine are un chibrit? Who has a match?" "Ea are o scrisoare din Statele Unite. She has a letter from the United States." "Elevii ascultă lecția. The pupils listen to the lesson." "Cumpărăm carne. We are buying meat." (Churchill 1998, 89, 90, 91, 92.) The Vampire (not dressed as a vampire based on the director's instructions), who just started talking with the Dog at first, came to the site because of the revolution: "I came here for the revolution, I could smell it a long way off." (Churchill 1998, 109.)

17 It is the author's instruction that the director should not be afraid of long silences (see Churchill 1998, 86). 
dance choreographed based on fragments of phrases. The show ends with the non-human voice of the Angel-Vampire couple in the midst of flesh-and-blood people, which places thus the events in-between the real and the unreal. ${ }^{18}$

Harun Farocki and Andrei Ujică's Videograms of a Revolution (1992) contains an archive of found footage selected from contemporary private and institutional video recordings, and stages the (non)human presence of the cameras during the event. The editing work of the authors (cuts, repetitions, captions for characters, intertitles, narration, viewpoints placed side by side) proves that the two (power) positions of the cameras cannot replace each other. The static camera connected with the position of power and the wobbling "freedom" of the moving, embodied camera taken from the stand and placed on the shoulder, breaking the hierarchy, present the meeting of the different uses and ideologies reflected in the camera positions. ${ }^{19}$ The cameras gradually become visible, corporeal protagonists. They become reflected agents, their varying presence is attached to various narrative strategies, and for a short while (four or five days) the television image and the recording camera become the producer, the space and the storage of the vortex of images.

A decisive element in the film from this point of view is the three-part division of the recordings of the last public speech. The 21.12.1989 Bucharest, Zum letzten Mal live (For the last time live) and the Eine Kamera erkundet die Lage ( $A$ camera investigates the situation) all signal the simultaneity of the centralized and polarized amateur version of technology. Ceauşescu losing all his resources for intonation and gesture pounds the microphone which (no longer) transmits as a prolongation of body and power, and shouts hello as if on a phone, trying to regain control over the crowd. Next to him, Elena Ceauşescu shouts in a strong and determined voice "Silence! Silence!" (Linişte! Linişte!), while saying the exact opposite to her husband in a silent, more intimate, encouraging tone: "Speak, speak!” (Vorbeşte, vorbeşte!) They both perceive the situation, but have different reactions. How the representatives of power used technology and language indirectly shows what kind of "audience" they assumed. It also signals how they reduced the reaction possibilities of the crowd to (technical/learned) actions: silence, ovation and applause. The orientation in these practices was guided by the intonation and

18 See: "ANGEL. Zburând în albastru. (Flying about in the blue.) VAMPIRE. 11. Nu-ți fie frică. (Don’t be frightened.) 14. Nu sunt o ființă umană. (I’m not a human being.) Începi să vrei sînge. Membrele te dor, capul îți arde. Trebuie să te mişti din ce în ce mai repede. (You begin to want blood. Your limbs ache, your head burns, you have to keep moving faster and faster.)" (Churchill 1998, 144.)

19 For an interpretation of the two types of camera use, see Pârvulescu (2013). 
pauses in the dictator's speech, this way they, the orator and the crowd together, reduced the language as a medium to variations in intonation and pauses. When the speech was interrupted Elena's instructions maintained the above communication strategy. Ceauşescu loses his position, shown both by his facial expression (he bites his lower lip, his gaze becomes uncertain) and his shouting "hello," and calls to the crowd like when a phone conversation is interrupted, addressing the crowd, unaware, probably for the first time ever under the influence of the chaos. The panoptic structure of visual choreographies organized very often for the couple, especially in stadiums (where the colours, shapes, letters displayed by the crowd were readable from above) was transformed, the (silent/cheering) sight of the crowd turned into a turmoil, the sound technology which operated the communication of power had broken down, and all these were indirectly also indicated by the interruption of the television broadcast [Figs. 5-7].

Figure 5 shows through the camera how the live transmission is interrupted because of technical problem, Figure 6 displays a red image on the screen, which in spite of what it says (live transmission), no longer broadcasts. Both of the images show an unusual visual problem, one through the disrupting image, the other through the contradiction with the caption. While the live transmission is disrupted, one of the cameras films only the sky (but records the sounds) [Fig. 6]. There is another camera that moves from its position and follows the dictator's gaze, as if becoming his own gaze, filming (and localizing) the movement and turmoil of the crowd, which causes the uncertainty and horror on his face [Fig. 7]. The invisibility of the power medium becomes visible because of the interruption of the live transmission, and this media glitch betrays the attitude of a medium, which had previously served the power in a manipulative way. The images of the Videograms fit together the divergent viewpoints of the archival records, displaying on the one hand the technical interruption of the live transmission through the static camera that recorded the speech, which (according to the instructions, in case of problems had to film the sky) still transmitted the excited voices on the balcony and the turmoil of the crowd. On the other hand, they also display the red square on the screen, which says live transmission, but there is no transmission. At this point, the image of the recording camera and the TV screen can still be separated. The separation of the image and the sound in the case of the camera (the camera filming the sky versus the turmoil of the crowd heard in the background), the short disruption of the recording camera and the "transmission" on the screen stages how the elements of the manipulated live transmission fall to their technical pieces. Clearly, this is the breakage, which 
most authentically materializes the events of the time. The transmission was not "taken away" like electricity, it was not the picture tube TV set that had broken down, but the transmission was interrupted in a previously unknown way. During the speech, in parallel with official camera positions, the events of the street also created private camera positions: the personal viewpoint of the camera filming from a private flat, moving carefully from the TV screen to the window, in the protecting cover of which it records the events on the street [Figs. 8-9].

The television image and the street are still separated here, they become each other's extension in a Baudrillardian sense after the Ceauşescu couple's escape at 12:08 on the $22^{\text {nd }}$ of December 1989, also documented by cameras. The studio becomes a new location of history - not a retrospective space of transmission, but a performative shaper of the events taking place in the street, and a scene of the events. More and more cameras "look for" the revolution on the streets and squares, transmitting heterogeneous, chaotic images. The divergent functions of camera and the television, shaping and documenting history at the same time, gradually settle back to their earlier conditions and become controlled. (After a while, the camera is sent out from the room being already under the control of Ion Iliescu, and another camera is waiting in the lift during a conversation with the director of the television company.) This way the freed, chaotic image production from before the restoration of power strengthened the new power's legitimacy to set a new order. The martial court of the Ceauşescus was recorded by a single camera, which could have also documented the execution of the sentence, had it not missed the shots fired, so it could only record the dead bodies. The official justification said that the camera battery had just discharged, as we find out from Radu Gabrea's re-enactment. ${ }^{20}$ On the news it was first announced that the Ceauşescus were executed and that the images would be shown later on; the interruption, the retroactivity is also symptomatic of the new censorship. The presenter tried to report the news in an articulate, neutral voice, but his short throat clearing still signalled the extraordinary event. The viewers could follow the enumeration of the charges on the screen later on, read by the voice of the presenter, who narrated the sentence and its execution over the image of the couple still alive and forced into a corner by two tables (pausing for 15-20 seconds). Finally, they could see their executed bodies. All of this is perceived in various ways in Videograms. In the television building, there are some people

20 This work that re-enacts the execution and the trial not shown in its entirety on television then, also reveals that it needed special negotiations with the representatives of the FSN to be allowed to transmit scenes from the trial. 
in a studio who reproduce the images on the screen with cameras and sound recorders, and watch the transmission through camera lenses, in another studio they applaud at the same image, in private homes they point at it, highlighting the mediatedness of the spectacle, or watch it silently, adults and children alike.

The cameras filming the viewers in TV studios and private homes show the event-like nature of viewing. These images represent the duality and simultaneity of seeing and being seen. The camera "sees" the faces looking at the TV screen in private spaces. Media circularity, multiplication and re-medialization is at play: the viewers are turned into images that can be stored, carried and edited, while they themselves are watching the unique traces of the (unrecorded) execution of the dicator and his wife (i.e. of the corpses) on TV, as untouchable images.

The face of the old woman in Figure 1, pictured in a private space, is difficult to interpret, but her gaze pricks and bruises like a punctum in the sense described by Roland Barthes in his book on photography (Barthes 1982, 27). It confronts us with the dual (both revealing and concealing) nature of the medium, the vulnerability exposed by the moving, embodied cameras.

Farocki and Ujică's work - except for the title and the end title - is framed by the confession of a woman and a man shot in emotional close-ups. The way these two people turn towards the camera also shows the contemporary camera use of private individuals. In the opening image, the camera transmits the strong emotional message of a woman on a hospital bed. The wounded woman's use of language and media employs the camera as a universal messenger, and posits herself as the subject that produces a message that reaches everyone - just like the dictator. Even her emotional intonation becomes perhaps similar to Ceauşescu's propaganda intonation. The final images of the Videograms display a different attitude: a worker voices his complaints and accusations about the dictator. He enumerates the mechanisms of discrimination and hatred, gradually becoming emotional and finally starting to cry, covering his face with his hands. ${ }^{21}$ When he fell silent, his peers applauded him (similarly to how the dead bodies were applauded in the studio), as if there were no other bodily or technical ways to relate to a crying man than applause and ovation, after the decades which had conditioned or reduced people to these bodily reactions. Today's viewer, while not seeing the man's emotions and the protective covering of his face as a staged scene, must also experience, by this reaction of applause, the traces of a theatrical reception, the conditioning of the

21 There is also a reference to nationality issues in this scene of Farocki and Ujică's work. The man crying in front of the camera speaks about himself as a victim of manipulation and hatred against Hungarians and Germans. 
age. The covering of the face in the epilogue raises awareness of the camera, of the instance of the becoming (and the circularity) of the image [Fig. 10].

Just like the images of the old woman's punctum-like gaze recorded from multiple angles, this image also "confronts" the viewer with an intimacy, with a vulnerability in front of the camera, which was only possible in an age when neither the recording person, nor the people being filmed would have guessed the unimaginable prolification and circulation of these images later on. This series that Farocki and Ujică intentionally placed at the end of their work may also raise the awareness of today's viewers about the nature of remediation understood as appropriation (see Bolter-Grusin 2000, 65), suggested by the personal, emotional, bodily reaction (the covering of the face) that (unconsciously) resists media translation. The events recorded by the archival images also cause some sense of shame in (today's) viewers. The feeling of unauthorized gaze is created by the paradox between the technical possibilities of the age and human conditioning: as the embodied and freed hand-held camera wants to broadcast endlessly and violently.

Later filmic re-enactments continued the basic visual experience of Farocki and Ujică's work, a multiplication of viewpoints, and transformed the intimacy of past events into present through the tension between retrospectivity and performance. The repetitions and editing work - as something that indirectly reveals the gaps in the understanding of the Romanian historical events - emphasize the transitionality, in-betweenness, heterogeneity of the "new beginning." It is because of this that Farocki and Ujică's work had become a model that could be developed in several directions by later films.

\section{Acoustic Past, the Studio as an Extending Space}

Corneliu Porumboiu's 12:08 East of Bucharest (A fost sau n-a fost?, 2006), in addition to being a parody of positivistic approach to history, reflects the revolution as an event and the media elements of the revolution (camera use, television, telephone, studio). Through the parody of the genre (a talk show), it also produces a grotesque, distancing and including the viewer's position at the same time. Porumboiu's film stages the tension between the revolution as a media event ${ }^{22}$ and as an event of one's personal past. Somewhere in a small town in Romania, sixteen years after 1989, a talk show host invites "eye witnesses" to take part in a discussion at the studio. He tries to locate the revolution in time and

22 For a summary of its discursive context, see Petrovszky-Tichindeleanu (2009). 
space with the help of a positivist view of history, and fails. The film reflects on the possibilities of the medium in evoking past events, and reveals how the ingredients of socialization in Communist times (e.g. intimidation, each other's surveillance and denunciation) are present sixteen years later too, and how certain mentalities still have not changed. The film produces the atmosphere of the acoustic past of the revolution - and this is one of the main reasons why it can be considered a re-enactment. The noise of the firecracker sounds like a rifle - Uncle Pişcoci, the common man in the show, the figure who embodies the intimate, family perspective of the "great historical event," ${ }^{23}$ even holds his hands up in fear as he hears it at the doorstep of his house. The TV set that breaks down also crackles in the old man's house producing a sound that reminds us of the past. The man who phones in during the talk show, formerly a Securitate officer, now an entrepreneur, also has a disciplining intonation, an intimidating articulation, effectively transforming the talk show into an interrogation. The Romanian title, reminiscent of Hamlet's question, varies along the talk show, from the first long question (Was there or wasn't there a revolution in our town?) through various versions and at one point it turns into an interrogatory question directed at Mănescu, the history teacher, ${ }^{24}$ like this: "Were you or were you not (there, in the main square)?" The Romanian question seems to challenge the very being of the interrogated person.

This film also stages the tension between a handheld and a static camera through the conflict of the cameraman and the host/producer. The TV show host orders the use of a static camera, but the cameraman wants to follow the events with a camera on his shoulders. During the debate, the camera follows the gestures of the investigators and tries also to point at the invisible traces on the poster on the wall in the background that represents the town square in a later state. We see a (virtual) space with multiple layers, and these layers both cover up and reveal the past: the poster, the transmission of the show and the physical presence of the broadcasting camera can be perceived all along because of the image errors following its clumsy movements [Fig. 11].

While the talk show host is concerned with the transmission of the images and the factual investigation of the past, his guests, just like the embodied camera that follows them, always fall out of this frame. The show gradually turns into a personal

23 Uncle Pişcoci, who can be seen here as a representative of oral history, stole two magnolias for his wife on December 21, 1989, to reconcile with her. He watched the live transmission on television, he was happy because of the extra money announced by Ceauşescu, and he confessed that he only went to the square after the dictators escaped.

24 His name is reminiscent of Manea Mănescu, former prime minister, Ceauşescu's brother-in-law, who also left Bucharest on the escaping helicopter. 
attack: they use formal and informal language alternately, they make references to each other's previous lives, and they all step outside their role of remembering the past. The voice and character of those who call in extend the space of the studio to include all the inhabitants of the town, and changes the show into an amplified space of interrogation. The talk show as the space of expressing one's opinion turns into a parody through the failure of the evocation of the revolutionary past. At the same time, it appears as the sound space that amplifies the mental state of the town inhabitants and uncovers the surviving mechanisms of the dictatorship: the denunciations based on surveillance, the hierarchy based on intimidation.

Porumboiu's film is about the impossibility of reconstruction, and reflects its human and technical conditions. Supposedly, there is nothing to reconstruct, for the present contains that which had not happened in the past: the lack of the revolutionary turn. The main square and the past events that took (or rather did not take) place there are "covered" with the chaotic presence of the people in the studio. Ironically, in the quietness of the empty studio the cameraman "fixes" the static camera on the motionless poster on the wall. The perfectly set relationship of technology and product (the image) stages the visibility of the space, the film returns to the camera, its static (inhuman, bodiless) independence through the undisturbed "gaze" of the camera directed at the still image of the poster. This situation indirectly reflects the human and technical conditions of the understanding of the past. The empty seats and the camera that was left there ironically create the possibility to think of the historical event as a circulation of images that replace the human participants, it offers the silence of images after the chaotic voices of people [Figs. 12-13].

The cameraman's action to shoot another image after the show can be interpreted as a metaphor for the viewers who create their own inner images as well after the show in their lonely silence. There is also an interesting linguistic analogy included into the show through Uncle Pişcoci, one of the participants. At one point of the show Uncle Pişcoci says: "Sir, we made the revolution as we could, we made the revolution our own way." According to his analogy, the revolution is like city lighting, it lights up in the centre first, then it spreads to the last miserable street as well. He shows the succession with his hands on the table, explaining that first it started in Timişoara, then it spread to Bucharest, then in the end to the "bottom" of the country, to their town. ${ }^{25}$ At the end of the film, the

25 This remark can also be regarded as an allusion to the fact that Timişoara was the first European town where electric street lighting was introduced. See: http://history-of-lighting.org/xviiiiluminatul-public. Last accessed 01. 05. 2017. 
cameraman who films the (Christmas) snow waits for the street lamp to light up in front of the camera, as if a visual denotation of the "light" of the revolution and of Christmas. The light of the lamp that stands in the falling snow in front of the greyish-bluish block may be ironic, but it also shines through the visual composition making it intimate under the falling snow [Fig. 14].

While waiting, the cameraman's voice-over tells us that the old man is wrong, because the lamps are operated by photocells. The lamp lights up automatically when sensing the diminishing light on the basis of the preset values of light. The argument also carries the power of the analogy. This way, besides the concept of history understood as the circulation of images, the film also signals the human version of the comprehension and transmission of events through language, and the transfer of the past through linguistic images, and also expresses the connection between linguistic imagination and the prevailing technical conditions. By this analogy, the contact of the generational perspectives points out that public lighting was centralized in Communism (and it was "taken away" at will), and that Uncle Pişcoci's worldview is also guided by this logic, and that a changing technical instrument also changes how the functioning of a revolution can be "imagined." The cameraman keeps the basis of the analogy (the connection of the revolution and public lighting), only that he sees another type of public lighting, and this way the compared element can also be imagined differently. The revolution becomes visible and transmittable as a linguistic analogy, then the analogy returns to the field of electronics, to reflect back enlighteningly on the revolution, which, in the sense of the analogy, was "triggered" by a darkness/ dictatorship that had become natural. The private memory of the cameraman replaces the failure of reconstruction with an aesthetic effect: "Silent and nice. This is all I remember from the revolution. It was silent and it was nice." He includes the silence of the snowfall into the acoustic atmosphere of the shooting, not as a sign of something missing, but as a relationship of the natural and the aesthetic, as the natural perceived in the aesthetic effect. But here the aesthetic effect lies not in its uniqueness, but in its most general meaning (i.e. it is nice), it rather becomes thus subservient to social amnesia. ${ }^{26}$

While it stages the possibilities, modes and human failures of remembrance, the film also addresses this embellishing type of amnesia at the end of the film, and appeals to the viewer's own visual and acoustic memory. The composition and

26 The last person who calls in, a woman, also calls attention to the snowfall. She says that her own child died in the revolution, and that the participants of the talk show should be pleased about the snow before it melts. 
colour of the image and the emphasis on the lamp may evoke the opening images of Farocki and Ujică's film. In the case of the images shot from the window of the student dormitory in Timişoara, the narration stresses the difference between events in the foreground and background, the blue sky in the background of the blocks of flats, the people marching on the streets, i.e. the position of the amateur camera filming them, the protection of the window and the technical data of a camera in that age. The street event becomes visible in the background through the reduced technical possibilities of zooming and the fear [Fig. 15].

The complexity of Porumboiu's film can also be experienced in the last scene's visual and acoustic power to evoke various archival recordings. The cameraman, while waiting for the lamp to light up, counts from one to five, and the calmness of his counting may remind us of the counting of another cameraman in the Farocki and Ujică's film, an employee of the Romanian Television Company (TVR) at minute 51.25, who we hear behind a black screen for a short while. The image gradually turns into a broadcast at count ten [Fig. 16].

After these images that probably show bullet traces, we hear Ion Iliescu's first speech from the balcony, with some technical interruptions. Before the black screen, and after the resignation of Prime Minister Constantin Dăscălescu, which eventually happened after three announcements, we hear the speech of Dumitru Mazilu (a Romanian diplomat emigrated to the West) from the same balcony. While Mazilu listed all the elements of a democratic system (reorganization of education, breaking with Marxism-Leninism, elimination of lying and deception, criteria of competence), Iliescu victoriously announces that the Ministry of the Interior is now subordinated to the Army, a new, centralizing power field, which is followed by applause. (The army now commands the troops of the Ministry of the Interior; the army has the supreme command. The Ministry of the Interior is their subordinate.) The black screen has therefore a dividing role as well: it stages the difference, the boundary between two possible "beginnings." The final images of Porumboiu's film evoke visually and acoustically disparate memories from the collective media archive of the 1989 revolution, the elements of the event seen on the archival footage can be dismantled when seen from the perspective of film images recorded later. In the last scene, which is centred on the recording camera as a character, the film also conveys a reflection of the social responsibility of creating an image, of making a film. 


\section{Play-Spaces, Recontextualized (Private) Stories}

Petra Szőcs’s 2014 short, The Execution stages the narrative nature of the child's gaze (like the one we saw in the archival images in Farocki and Ujică's film). In the film, placed in a Romanian and Hungarian language context, we see three elementary school children as they narrate, embellish, embody and domesticate the images of the trial and execution of the Ceauşescus to their own family space. ${ }^{27}$ In the centre of the film lies the discrepancy between the smiling pictures of the dictator couple and the sight of the dead bodies. The film places two modes of play side by side, and sharpens the difference between them from a child's inner perspective. On the one hand, there is the game Gazdálkodj okosan! (a Hungarian version of Monopoly), with the parents' fight in the background, as a possible cause of the little girl's aggressiveness (she stabs her classmate's hand with a pair of scissors). On the other hand, there is the obsessively replayed execution and death, which stages how the event broadcast on television had been implanted into one's own body and the concept of the family. It sounds really eerie and undetachable from the little girl's character when she, as Elena, says: "I don't want to die!" [Figs. 17-18.] The trial and execution images archived probably as memories gain a double reality and voice in this children's game.

Irina Botea's Auditions for a Revolution (2006), produced in Chicago, stresses the theatrality and (visual) masculinity of the scenes recorded during the revolution through re-enactment. The filmmaker defines the Romanian revolution in-between the reality of the television and the reality of one's own life, where the participants seemed like actors (see Picard 2011). The textual fragments produced with physiological struggles by young Americans, who speak no Romanian and are not familiar with Romanian culture turn the intonations and gestures of a "revolutionary language" into "meaning conveying" elements. By their performance and language production, they turn the archival images into a theatrical event, the linguistic memory fragments into history read aloud. They create the historical/theatrical event alienated by their acting performance, but physiologically their own. The re-enactment scenes were recorded with a camera of the leading Romanian documentary studio, the Sahia Film, which was used also during the revolution. Due to the weight of the camera, the recording of the (reenacted) footage also required a physical effort on the part of the female director.

27 The mingling of the concepts of family and country (the country as a large family and the leaders as parents) was a part of the basic ideological conditioning of children during Communism. For a literary treatment of the subject, see Herta Müller's A Big House (Müller 1989, 50-52). 
At the same time, the film also shows the archival footage from Farocki and Ujică's film and its re-enactments on a screen divided by means of digital technology. This visual simultaneity creates a permanent relationship and oscillation between the technical conditions of the present and the past, between the television images and the re-enactments, all in a virtual space. The participants of the revolution referred to their action saying that "the world is watching us," and by this they defined technology as an extended mediation, and themselves as a spectacle.

In this performance the foreign gaze gains voice and body, embodying the imagined and assumed viewers of the age. The "translatability" of the gestures and intonations of the foreign language dissonance becomes more visible. The young Americans who instead of viewers become performers understand and fail to understand at the same time what they say, they play and experience the distinctive media/physical traces of the Romanian revolution. On the basis of Inke Arns's ideas cited earlier, they turn the events of the past into a history happening here and now. They inscribe the gestures of a foreign event into their own bodies, their own present. A performative staging of this is done through the rhythm of chanting, which turns the scene of the revolution into a present that is just happening. After the struggles of reading Mircea Dinescu's sentences broadcast on television at that time, the young Americans are eventually freed from the unpronounceable Romanian text, and enthusiastically chant the Romanian version of "We won!" "“Am învins!”). This enthusiasm is stopped by the director's "Cut! Cut!" exclamations, who interferes thus with the (re)activation of the body's memory and also signals the intention of the directorial authority in the re-enactment this way [Fig. 19].

Sound and image form separate strata: the images of the streets of Chicago are accompanied by Romanian sentences from archival recordings, while the reenacters fill the (western) spaces created through their marching with the voices of their chanting (“Freedom/Libertate!," “Truth/Adevărul!”). It is as if their voices and gestures extend/translate the archival images of the past Romanian events into their own life space. The slogans and gestures are like quotations mediating the history of Eastern Europe. Due to their strangeness, we also sense their aggressive/theatrical embeddedness into their Western space and their own bodies. Their physiological struggles also stage the aggression of re-enactment, while the play, the repeated bursts into laughter also signal the freedom of making it their own. During the re-enactment, the transposed Romanian events turn the American town space into a "practiced place" (de Certeau 1984), and this way they simultaneously and rhetorically "read" the archival images of the past events and the American town space. 
The Chicago actors make the archival images "readable" and make us reflect on them through their personalized rendering. However, in Botea's re-enactment the presence of girls showcases the masculine dominance of the archival images, that no women are found in any of the decisive situations. On the other hand, the narrative of the archival images shows feelings and emotions only on female faces. In the festive TV studio, during the theatrical Christmas speech of actor Florin Piersic, we mostly see tearful female faces. The only weeping male face is also visible on the archival images in Botea's re-enactment. Therefore, this performance emphasizes, strengthens the image of a weeping man, reminiscent of the end of the Farocki-Ujică film (the "sight" of the man bursting into tears), not a decisive image of the visual agenda of the age.

The use of a divided screen keeps the viewer in a permanent confusion, forces them to always change their focus, they can never watch the entire screen at once, because the eye always jumps to one side or the other. Next to the disquieting gaze of the old woman (getting into media circulation) on one side of the screen, we find the media contexts on the other side (TV screens looking at each other, telephone, sentences to be read aloud, the bodily presence of the re-enactors, symbols), but her silence is not dissolved by these, even if the image has an added caption with the translated sound of the original TV broadcast [Fig. 20].

\section{The Handheld Camera as a Weapon}

Milo Rau's project The Last Days of the Ceaussescus. Re-enactment of the Ceauşescu-Trial (Die letzten Tage der Ceauşescus, 2009/2010) and Radu Gabrea's film Three Days Till Christmas (Trei zile până la Crăciun, 2011) re-enact the trial of the Ceauşescus by the exceptional military court - not broadcast in contemporary media - which condemned them to death and the sentence was executed right away. The complexity of Milo Rau's work also lies in the multiple media translation. Within the project supported by the International Institute of Political Murder, theatre performances were produced, a book was published and a film was created. The film which adds new layers to the theatre performance staged in Bucharest centres on the relationship of the event and its remedialization. ${ }^{28}$

28 The first play within the project took place in Odeon Theatre of Bucharest in the winter of 2009, followed by shows in theatres in Germany and Switzerland. Milo Rau's book Die letzten Tage der Ceauşescus. Materialien, Dokumente, Theorie [The Last Days of the Ceauşescus: Materials, Documents, Theories] was published in 2010 (Berlin: Verbrecher Verlag), at the same time with the release of the film. For details, see: http://international-institute.de/ceausescu/. Last accessed 15. 01. 2017. 
Already in the performance, the digital image strips projected onto the theatrical space suggest how the re-enactment in a sort of political theatre renders mediality problematic, and how the event cannot be localized to one single space. This is even more amplified in the film by documenting the production of the play and the audience. It is outstandingly important in this respect that Victor Stănculescu, a key figure of the play, appears indeed in the audience. In fact, he was serving his prison sentence during the performance, so his presence archived in the film opens up the space of political theatre on multiple levels. ${ }^{29}$ Milo Rau's film presents the trial and the execution as an event where the viewer cannot avoid the moral question, the dilemma of a (lawful) sentence and murder by various means such as dramatization, the staging of the viewpoints of eye witnesses and re-enactors, parallel memories and inner narrations, the opinion of viewers. The differences between body and role also contribute to the staging of the spatial differences of various perspectives. The actors play several roles: Constantin Cojocaru plays both Ceauşescu and Andrei Kemenici, the commander of the Târgovişte barracks. Victoria Cociaş plays Ana Blandiana, the poet in opposition, and Elena Ceauşescu. The firing soldier who speaks about his memories and the lawyer of the accusation are also played by the same actor. In the re-enactment, two people on opposing sides in the past event appear in one single body, and it depends on the performance of the actor how the historical figures are presented. Multiple distance is generated thus in the space of the re-enactment. On the one hand, we are constantly reminded (also through archival images) of the similarity and difference of the real past bodies [Figs. 21-22] in the present.

On the other hand, there is a difference between the body and its duplicated role. The past characters meet in a common body and diverge in acting. The characters less visible in the visual circulation of the age (Ana Blandiana, Andrei Kemenici) were embodied in relation to the Ceauşescus, but also taking apart their visual traces. ${ }^{30}$ In the re-enactors' exaggerated rendition, Elena Ceauşeascu's face seems more terrorized (and her gaze starts to resemble the gaze of the female

29 This enigmatic figure, after he was sentenced again in 2007 in a second trial (the first happened in 1997) for fifteen years of prison for his role in suppressing the revolution (Timişoara, the $17^{\text {th }}$ of December 1989), was finally imprisoned in 2008. He was released five years later for good behaviour and because of his ill health, and died in the summer of 2016, at age 88. Stănculescu, who had a key role in the events of the revolution was less visible in the images of the broadcasts from 1989, but as far as I know, he never got to publish his book with the working title Mona Lisa's Smile, mentioned as a plan in the film Checkmate.

30 Victoria Cociaş likens Elena's gaze to the terror of a cornered animal, and changes into something different in understanding this terror when she tells them to execute them together. The strong bond between the two people, visible in their last moments, also suggests their lives as a great love story (Cociaş 2010, 60). 
face watching the broadcast). She searches for the eyes of Stănculescu, who is folding a paper airplane during the trial. ${ }^{31}$

The re-enactment of the trial, which deployed sarcastic and offensive attitudes (they are addressed informally by their first names, the judge asks Elena about her age, which she had always kept a secret, they ironically hint to her intellectual abilities, etc.), highlights even more the couple's cohesion. Their similar gestures (such as taking their hands to their mouth) are visible on the archival images [Fig. 25]. Milo Rau's production is framed by an image fading into black and the sound of the blowing winter wind. The past event is placed into the atmosphere of a winter landscape (similarly to Porumboiu's snowfall at the end), while several attempts are made to represent the event through varied technical means, Rau's film also confronts us with the unreadable black screen. The sound and the invisible image, the gunfire "transmits" the lack of images. The retroactively inconceivable events become a liminal experience of the medium: the very possibility to experience and produce the missing (archival) image is what becomes problematic. The gunfire behind the black screen forces the viewer to create inner images [Figs. 23-26].

The title of Radu Gabrea's film, Three Days Till Christmas, similarly to Milo Rau's title, places time in the centre, but instead of the personified last days, it refers to the time of the feast. It burdens the feast of birth with the images of the execution. The work that mixes archival materials, interview fragments and re-enacted scenes unfolds the viewpoint of the dictator couple through the multiplication of various other perspectives. The time ironically understood as a turning point (12:08) in Porumboiu's film and the archival footage which films the helicopter from below as it takes off is followed in Gabrea's film by an upper camera shot of the helicopter. We also have the events of the street as they were described in the radio transmission, as "another" space, the sound of radio and later TV transmission is heard all along behind the escape perceivable also as a road movie. This way the chrono-topos of the travel becomes a heterotopic space-time. On the one hand, following the couple can have a documentary value: the film claims that the couple had completely lost control of the technical network, so they probably could not have given any instructions after their

31 This seemingly unimportant, casual action during the trial is evoked in Porumboiu's film through the figure of the bored Uncle Pișcoci, who also folds paper as a trace of his (non)presence. In Mircea Daneliuc's comedy The nuptial bed (Patul conjugal, 1993) the flying of paper airplanes appears as a nostalgic performance of people who yearn for a superior leader in the inner yard of a psychiatric hospital. The absurd present of the film, close in time to the 1989 changes, is also interwoven with archival images of the revolution. 
escape on helicopter, this way the hypothesis of "terrorists" guided by them is highly unlikely. On the other hand, our following them may remind us of the story of the Holy Family's flight, as we gradually get into the whirl of a carnival time. Various cultural time-experiences are evoked and stratified, shaping the viewers' positions. The events going on in various spaces are connected by the carnival spirit: the chanting in the street, following Mikhail Bakhtin, sounds like a suspension of the hierarchy, as a dethronement; and in the personal time of the couple, the change of clothes, the eating, the grotesque, sick body correspond to the carnival as a time organized around bodily experiences, manifested in time (Bakhtin 1984, 196-277). It is from this film that we find out that the flesh-andblood person behind the "retouched image," Ceauşescu, was diabetic. Another element that connects the events to a carnival atmosphere is the fact that the carnival time is an uprooted time that ends together with its liberating euphoria. The dethronement has a twofold consequence in the film: by the demolition of hierarchy, it may lead to accountable and intimate dialogues between the guards and the prisoners in the sense of a carnivalesque explicitness, while the "dethroned" gain their intimacy more and more as a fallible, elderly couple. But the camera movement indicates this fallibility immediately with keeping distance: we see their faces from up close, and at the same time their intimate physical closeness from a panoptic distance, from above [Figs. 27-28].

In Gabrea's film the hand-held camera can be seen in parallel with the use of the weapon of execution. While the trial was recorded by one single camera, and the execution was only partly recorded, in Gabrea's re-enactment the cameraman appears in the images in several instances, placing the camera recording the film itself into a self-reflective position. In the re-enactment, the camera appears near the weapon as a producer of the image of the untouchable corpses [Figs. 29-30].

\section{Epilogue: Chanting, Slogans, Analogy}

The historical and media position of the Romanian revolution is also made more complex by the fact that it was probably the last time that a poet as a historical public figure had such a decisive function in Eastern Europe, conveyed precisely by the medium of television. Moreover, the unique historical importance of the Romanian events may also be due to this encounter between the figure of the poet and the medium of television.

Paradoxically, the verbal announcement of freedom happens in the medium, which transmitted the static, setup world of the dictatorship. Mircea Dinescu, the 
poet who turned the announcement of victory into a performative statement by his arm swing, steps into the media space of the dictator, so in the re-enactments these archival images can also necessarily be seen in an ironic distance. The constructed image of the poet meeting the Socialist ideal who is still "working" in the time of the revolution is unmasked by the moving camera, for instance by the deframed images in Gabrea's film. During the chaotic preparation of the first free announcement transmitted on television, actor Ion Caramitru instructs poet Mircea Dinescu as follows: "Mircea, you show them you're working!", and while he points to the camera with a paper sheet in his hand, the frame moves and we fail to see their entire heads [Fig. 31]. In Milo Rau's work the image is broken into stripes, which becomes thus repeatable like a chorus, signalling the repetition of announcements or resignations, becoming thus parodistic [Fig. 32].

The re-enactments, which stage polyphony as a fundamental experience, do not allow for the historical role of poetry and the poet to be reduced to one single voice. In Milo Rau's work the poetess/actress in the role of Ana Blandiana connects the revolution as a "personal" story to the "sight of the voice" of groups chanting the slogans of freedom, grasping it in an intermedial image: "However, there was indeed a revolution, that moment full of hope existed... And now I'd like to tell a personal story too. It was December 21, evening, the revolution in Bucharest had been lasting for one day, I was standing in front of the wide opened window and looking out into the dark. They were chanting slogans in the dark. Sometimes it was all clear, sometimes not, depending on how far the groups were. These transmitted both hope and fear, and also surprise that they even got that far. The slogans later became clear. They chanted: Down with Ceauşescu! No violence! and The army is with us! The last two were like spells or requests, because in reality the army wasn't with us and was violent with us, at least at the beginning. These voices were so clearly floating in space that I could perceive them almost optically as a fluorescent inscription against a black background. Yes. And these voices in the dark is the first thing that appears every time I think of the revolution" (Rau 2010). The dark screen of the film is paralleled with the darkness in town, the voices and captions accompanying the (two kinds of) darkness, and the lack of image activates the viewer's imagination.

The poetic force of the voices "visible" in the dark translates the darkness (its resistance to visuality) to human imagination and perception as a sounding memory because of the chanting. The (poetic) image is also indebted to the singularity of imagination. By this image as an event of language turning into poetry, and by the film that stages it, the revolution can now also be perceived 
through the mediated aesthetic experience. The historical moments of the encounter between the television and the poet or poetry are created in Milo Rau's work from two different points of view: first, by the "found expression" (We won!) staged by the "working poet," Mircea Dinescu, as a physical and linguistic process; second, by the poetic effect of the fictive Ana Blandiana's remembering lines, which can be understood as a "caption" for the darkness of the (original) screen, for the missing images. Flusser's axiom can perhaps be continued this way: "There is no reality behind the image. There are realities in the image." But the technically recorded images also transmit the lack of images (darkness), and as such, there are subjective, poetic images that are "wedged" in-between them. However, in the flow of image production the archived images have also preserved the possibility of their silence, their resistance to interpretation and domestication. And this is how the silence of the old woman's face and the silent (televised) images of the couple just before their execution are placed side by side in my personal archive. Although these images can be watched, their mute gaze confronts us with the visual experience of the blank screens. They transform us into re-enactors because they force us to address them and lend them our voice.

\section{References}

Agamben, Giorgio. 2000. Marginal Notes on Commentaries on the Society of the Spectacle. In Means without End. Notes on Politics (Theory Out of Bounds), 73-89. Minneapolis-London: University of Minnesota Press.

Agnew, Vanessa. 2004. Introduction: What is Reenactment? Criticism vol. 46, no.

3: 327-339. http://digitalcommons.wayne.edu/criticism/vol46/iss3/2. Last accessed 01. 05. 2017.

Arns, Inke. 2007. History Will Repeat Itself. Strategies of Re-enactment in Contemporary (Media) Art and Performance. http://en.inkearns.de/ files/2011/05/HWRI-Arns-Kat-2007-engl.pdf. Last accessed 01. 05. 2017.

Bakhtin, Mikhail. 1984 [1965]. Popular-Festive Forms and Images in Rabelais. In Rabelais and His World, 196-277. Bloomington: Indiana University Press. Barthes, Roland. 1982 [1980]. Camera Lucida: Reflections on Photography. New York: Hill and Wang.

Baudrillard, Jean. 1993. The Timişoara Syndrome: The Télécratie and the Revolution. Columbia Documents of Architecture and Theory vol. 2: 61-71. Boal, Augusto. 2006. Games for Actors and Non-Actors. Theatre of the Oppressed. London: Routledge. 
Bolter, Jay David and Richard Grusin. 2000. Remediation: Understanding New Media. Cambridge-London: MIT Press.

Brandstätter, Susanne and Gabriela Adameşteanu. 2004. Şah-mat. Strategia unei revoluții. [Checkmate. The Strategy of a Revolution] http://revista22.ro/750/. html. Last accessed 01. 05. 2017.

Certeau, Michel de. 1984. The Practice of Everyday Life. Berkeley: University of California Press.

Cesereanu, Ruxandra. 2009. Decembrie '89. Deconstrucția unei revoluții. [December '89. The Deconstruction of a Revolution], Iaşi: Polirom.

Churchill, Caryl. 1998 [1991]. Mad Forest. In Plays: Three, 85-144. London: Nick Hern Books.

Cociaş, Victoria. 2010. "Ein in die Enge Getriebenes Tier.” [A cornered animal] In Die letzten Tage der Ceauşescus. Materialien, Dokumente, Theorie. [The Last Days of the Ceauşescus: Materials, Documents, Theories], ed. Milo Rau, 60-63. Berlin: Verbrecher Verlag.

Flusser, Vilém. 1990. Television Image and Political Space in the Light of the Romanian Revolution. April $7^{\text {th }}$, Budapest: Kunsthalle, lecture: https://www. youtube.com/watch?v=QFTaY2u4NvI\&feature=channel_video_title. Last accessed 01.05.2017.

Hall, Andrew Richard. 2016. Madalin Hodor, GELA*, and Me: How 20 years later details from my dissertation show up on Romanian TV. https:// romanianrevolutionofdecember1989.com/madalin-hodor-gela-and-me-how20-years-later-details-from-my-dissertation-show-up-on-romanian-tv. Last accessed 01.05.2017.

Hodor, Mădălin. 2016. Mitingul din 21 decembrie 1989. Epitaful unui alt episod al „loviturii de stat.” [The meeting of 21 December 1989. The epitaph of another episode of a "coup d'état"] http://revista22.ro/70259089/mitinguldin-21-decembrie-1989-epitaful-unui-alt-episod-al-loviturii-de-stat.html. Last accessed 01.05.2017.

Koselleck, Reinhart. 1979. Vergangene Zukunft. Zur Semantik Geschichtlicher Zeiten. [The Past Future. The Semantics of Historical Times], Frankfurt am Main: Suhrkamp.

Lefebvre, Henri. 1991 [1974]. The Production of Space. Oxford: Blackwell. Müller, Herta. 1989 [1986]. The Passport. London: Serpent's Tail.

Pârvulescu, Constantin. 2013. Embodied Histories. Harun Farocki and Andrei Ujică's Videograms of a Revolution and Ovidiu Bose Paştina's TimişoaraDecember 1989 and the Uses of the Independent Camera. Rethinking History: 
The Journal of Theory and Practice vol. 17, no. 3: 354-382.

Pascariu, Roxana. 2007. Responsabilizarea prezentului. Pădurea nebună. O piesă din România. [The Responsibility of the Present. The Mad Forest. A Play from Romania] http://www.revista22.ro/responsabilizarea-prezentului--padureanebuna--o-piesa-din-romania-3359.html. Last accessed 01. 05. 2017.

Petrovszky, Konrad and Ovidiu Tichindeleanu. 2009. Revoluția Română televizată. Contribuții la istoria culturală a mediilor. [The Romanian Revolution on TV. Contributions to the Cultural History of Media], Cluj-Napoca: Idea Design \& Print.

Picard, Caroline. 2011. Reenacting a Many Possible Past: An Interview with Irina Botea. http://blog.art21.org/2011/01/07/reenacting-a-many-possible-past-aninterview-with-irina-botea/\#.VvWj40AYFIW. Last accessed 01. 05. 2017.

Rothberg, Michael. 2009. Introduction: Theorizing Multidirectional Memory in a Transnational Age. In Multidirectional Memory. Remembering the Holocaust in the Age of Decolonization, 1-29. Stanford: Stanford University Press.

\section{List of Figures}

Figures 1-2. Harun Farocki and Andrei Ujică, Videograms of a Revolution (1992): disturbing gazes.
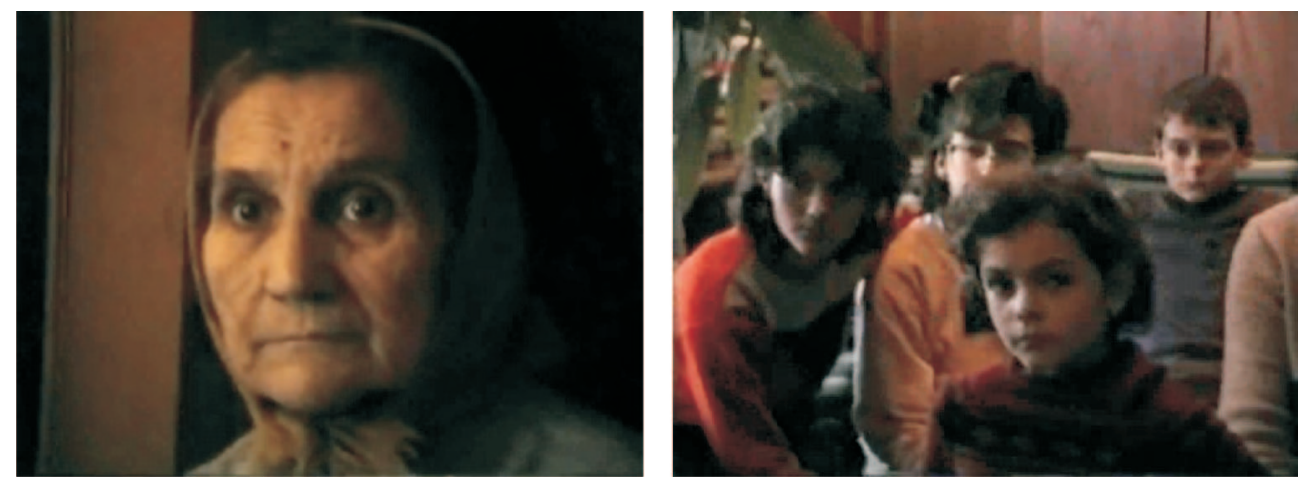
Figures 3-4. Harun Farocki and Andrei Ujică, Videograms of a Revolution (1992): the reality of the screen.
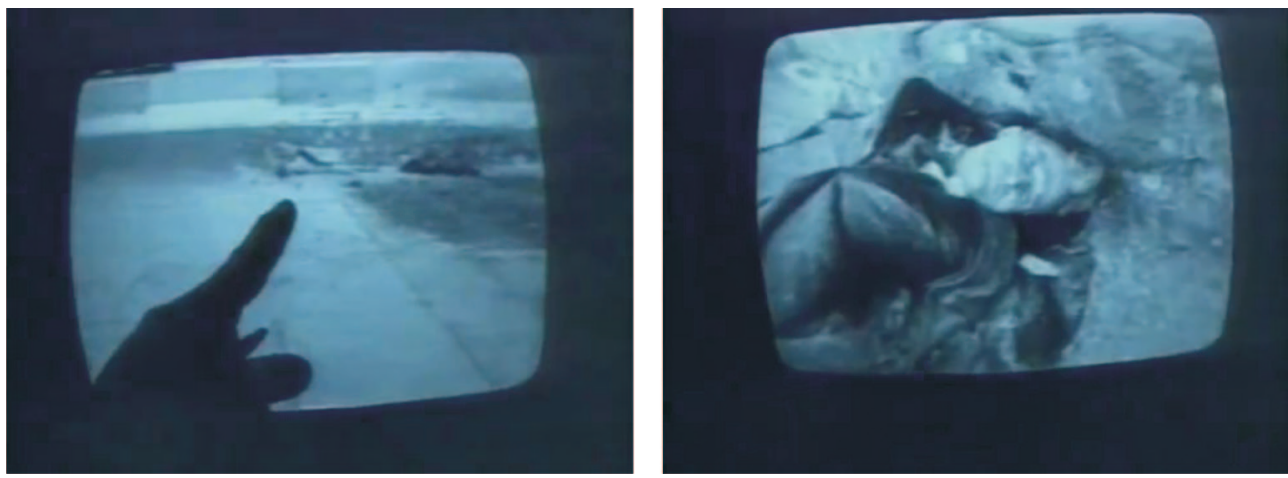

Figures 5-7. Harun Farocki and Andrei Ujică, Videograms of a Revolution (1992): technical problems, the live broadcast is interrupted.
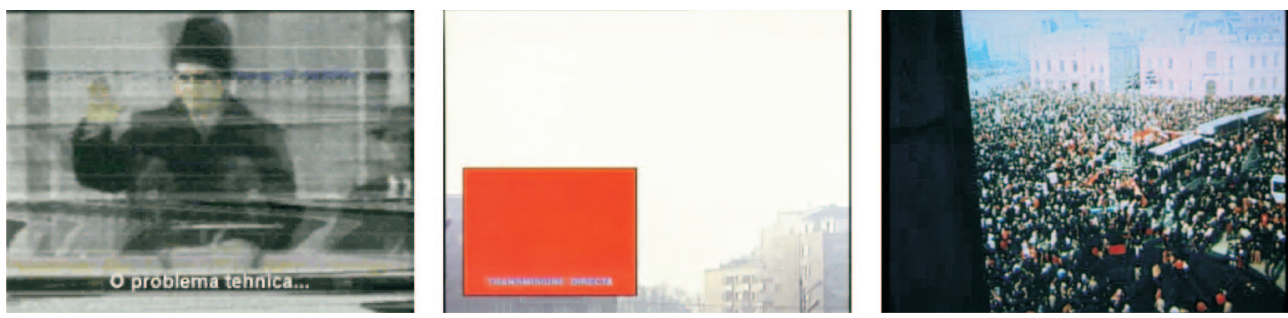

Figures 8-9. Harun Farocki and Andrei Ujică, Videograms of a Revolution (1992): an amateur camera in a private flat, venturing from the TV screen to the street. Figure 10. The involuntary bodily "reflection" of becoming an image.
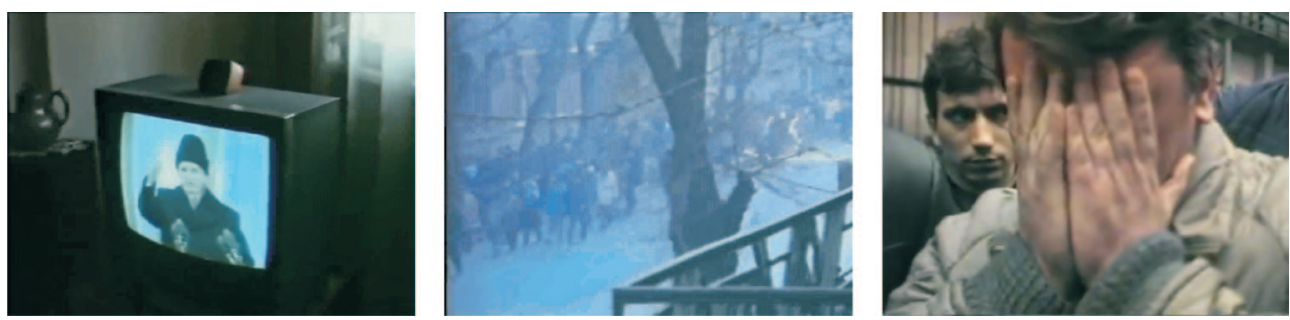
Figures 11-13. Corneliu Porumboiu, 12:08 East of Bucharest (2006): the camera turning, making the poster in the background visible.
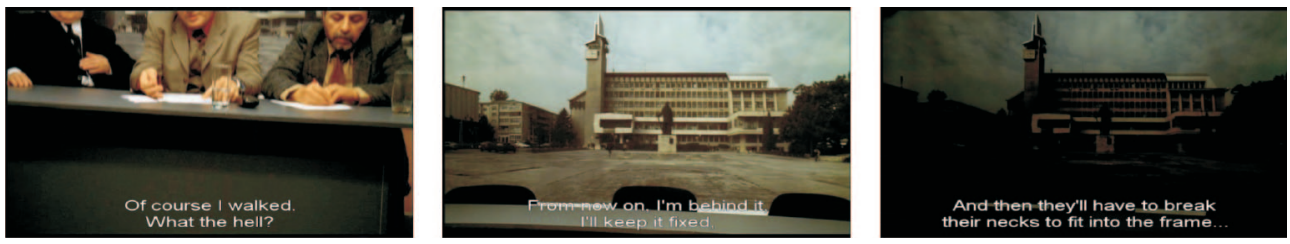

Figure 14. Corneliu Porumboiu, 12:08 East of Bucharest (2006): static camera, lamp in the twilight. Figures 15-16. Harun Farocki and Andrei Ujică, Videograms of a Revolution (1992): the endangered camera and the event in the background; black screen turning into bullet traces, the cameraman's counting as a boundary between two potential "new" powers.
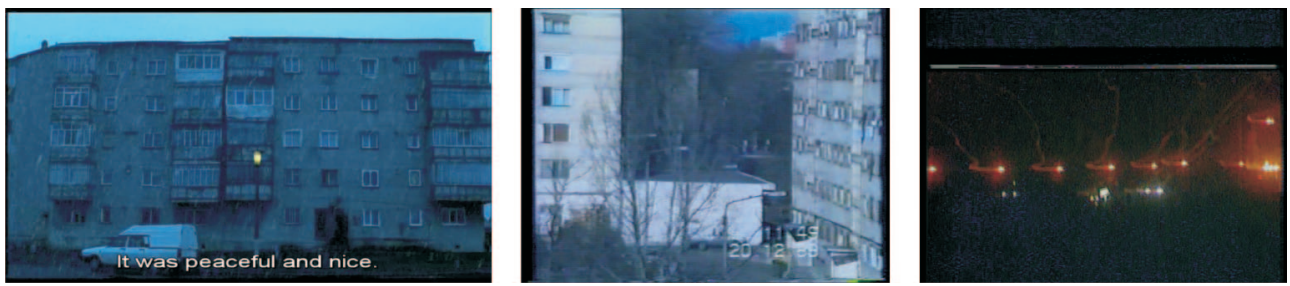

Figures 17-18. Petra Szőcs, The Execution (2014): children re-enacting the execution of the Ceauşescus.
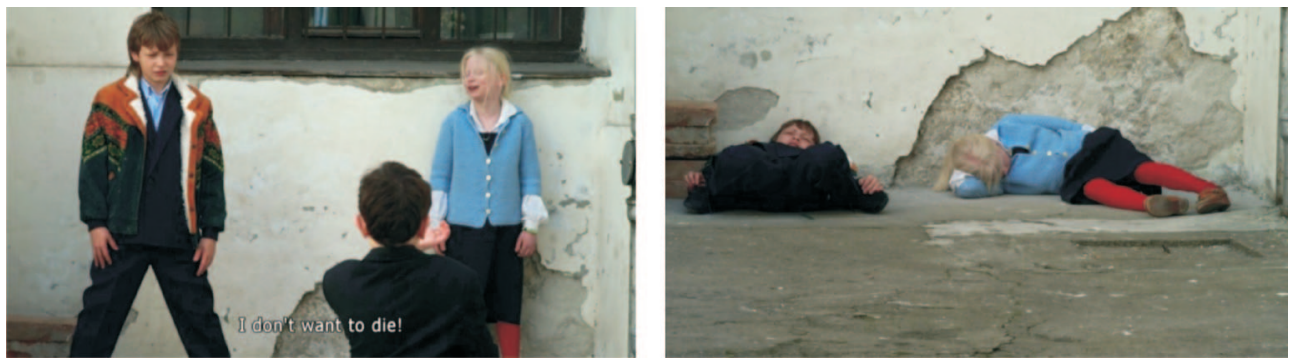
Figures 19-20. Irina Botea, Auditions for a Revolution (2006): the physical enthusiasm of the announcement of victory; a silent gaze, visually and acoustically contextualized.
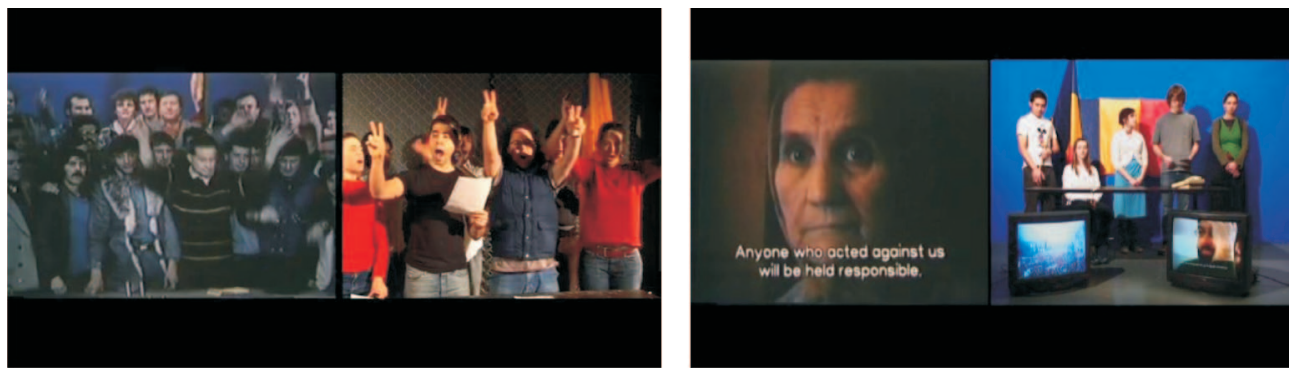

Figures 21-26. Milo Rau, The Last Days of the Ceauşescus (2010).
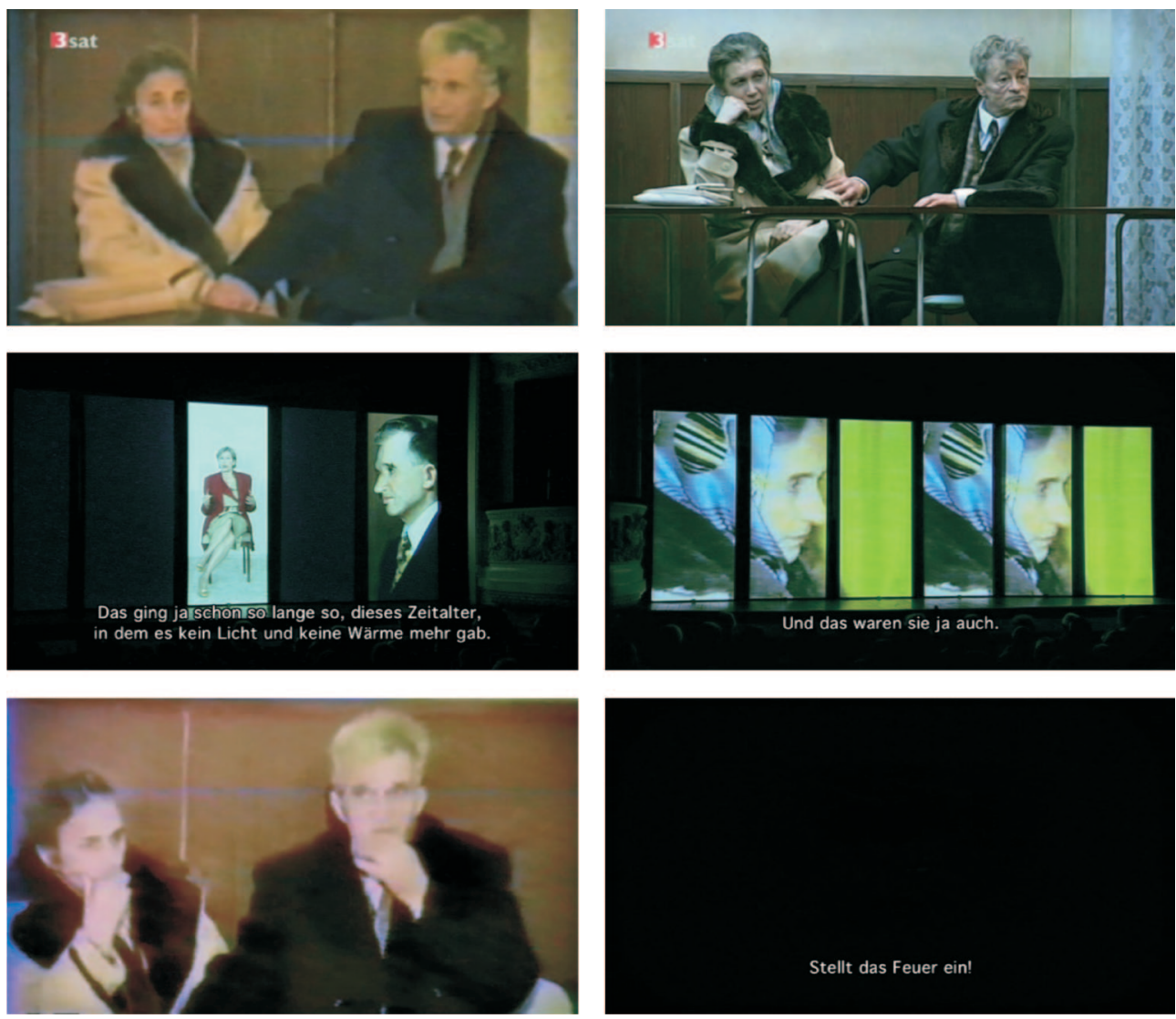
Figures 27-28. Radu Gabrea, Three Days Till Christmas (2011): an elderly, interdependent couple.
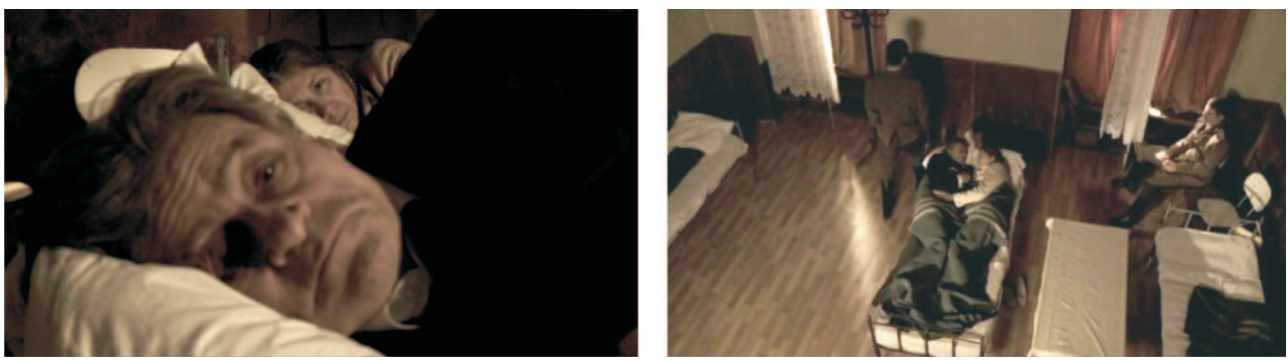

Figures 29-30. Radu Gabrea, Three Days Till Christmas (2011): the visual parallel of guns and hand-held camera.
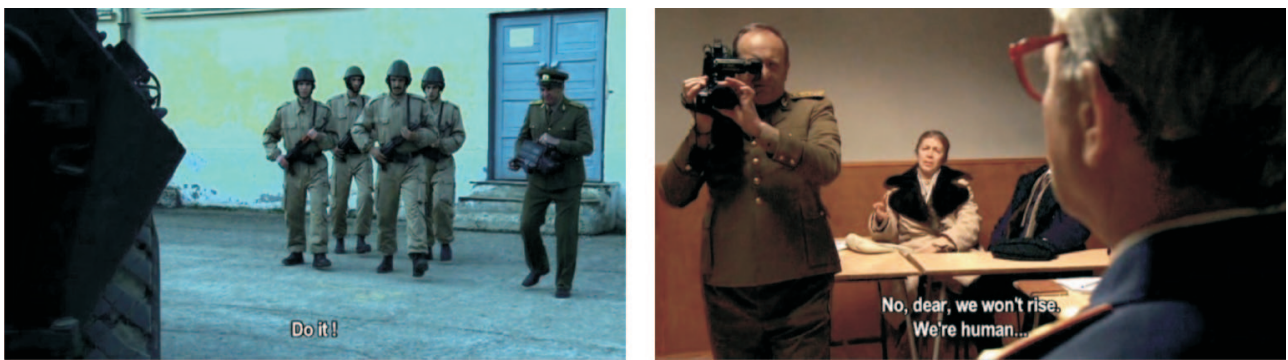

Figures 31-32. Radu Gabrea, Three Days Till Christmas (2011): the "working" poet and the moving camera. Milo Rau, The Last Days of the Ceauşescus (2010): the repetitive visual rupture of the announcement of victory.
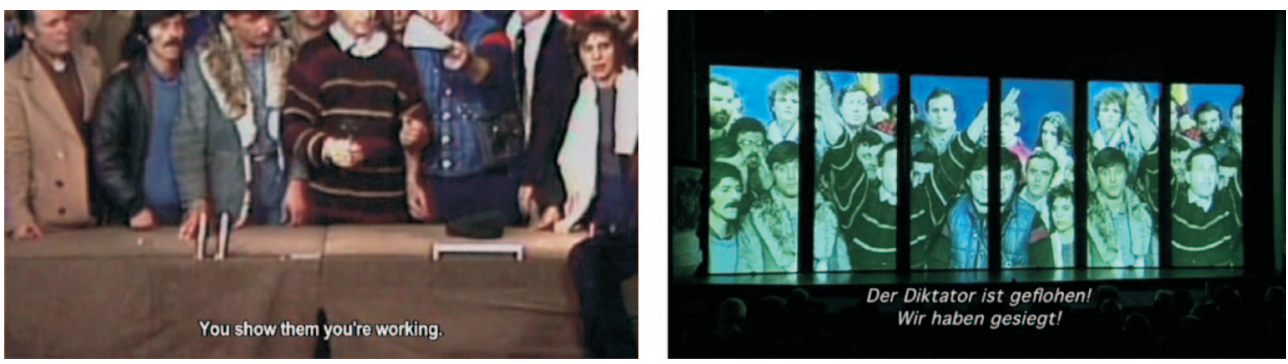